\title{
EFFECT OF ROSEMARY, CLOVE AND OREGANO OIL ON THE PRESERVATION OF VACUUM-PACKAGED HOT SMOKED TROUT
}

\author{
ADRIANA DABIJA ${ }^{1}$, MIRELA ARDELEAN ${ }^{2}$, MARIA POROCH-SERIȚAN ${ }^{1}$, MIRCEA ADRIAN \\ OROIAN ${ }^{1}$, AMELIA BUCULEI ${ }^{1}$, IOANA REBENCIUC ${ }^{1}$, DANIELA TEODORA MARTI ${ }^{2,3}$, \\ ANDREI LOBIUC ${ }^{1 *}$ \\ ${ }^{1}$ Faculty of Food Engineering, Stefan cel Mare University of Suceava, 13 Universității Street, 720229, Suceava, Romania \\ 2 "Vasile Goldiș” Western University of Arad, 94 Revoluției Boulevard, 310025, Arad, Romania \\ ${ }^{3}$ Emergency County Clinical Hospital Arad, Medical Analysis Laboratory, Microbiology, 2-4 A. Karoly Street, 310037, Arad, \\ Romania
}

*corresponding author: andrei.lobiuc@fia.usv.ro

Manuscript received: October 2018

\begin{abstract}
This study was performed in order to investigate the effect of essential oils (rosemary, clove and oregano) treatment on vacuum-packaged smoked trout quality changes over 91 days of chilled storage. Currently, the essential oils are used in food industry for two main reasons: to control natural spoilage processes in food preservation and to prevent growth of pathogens in food. In the current research, essential oils were purchased from a Romanian authorized company of essential oils with applicability in the food industry, and the product of the trout subjected to the investigation was obtained in an industrial processing company of the trout. Characteristics related to sensorial, physicochemical and microbiological (total aerobic counts, lactic acid bacteria, Enterobacteriaceae, Pseudomonas, Salmonella) properties were evaluated at 0, 14, 28, 42, 56, 70, 77,84 and 91 days of cold storage, respectively. The best results were obtained with the use of clove oil, which did not influence the sensory characteristics of the product.
\end{abstract}

\section{Rezumat}

S-a investigat efectul conservant al uleiurilor volatile de rozmarin, cuişoare și oregano asupra unor probe de păstrăv afumat, ambalat în vid, pe o perioadă de 91 de zile de depozitare refrigerată. În prezent, uleiurile esențiale sunt utilizate în industria alimentară din două motive: controlul proceselor naturale de alterare în conservarea alimentelor şi prevenirea creșterii agenților patogeni în produsele alimentare. În studiul prezentat, uleiurile esențiale au fost achiziționate de la o companie românească autorizată, producătoare de uleiuri volatile cu aplicabilitate în industria alimentară, iar păstrăvul supus analizei a fost procurat de la o fabrică de prelucrare industrială a peștelui. Caracteristicile senzoriale, fizico-chimice și microbiologice au fost evaluate la $0,14,28,42,56,70,77,84$ și respectiv 91 de zile de depozitare la rece. Cele mai bune rezultate au fost obținute prin utilizarea uleiului de cuișoare, care nu a influențat caracteristicile senzoriale ale produsului.

Keywords: food preservation, essential oils, antimicrobial activity

\section{Introduction}

Trout is a fish belonging to the Salmonidae family, a species with high commercial value and much appreciated by Romanian consumers and not only [1]. These fish are highly nutritious, rich in vitamins, proteins and minerals [2]. Smoking is a traditional preserving method used for fish and meat products around the world which also applies to trout. Smoked trout, usually stored in refrigerated conditions, is very sensitive to spoilage and has a limited shelf life of usually 3 - 4 weeks and up to 5 weeks if the product is vacuum packaged [3-5].

Improvements in the shelf life of smoked trout product can have an important economic feedback by reducing losses attributed to spoilage and by allowing the products to reach distant and new markets [6-9]. An effective method for the extension of shelf life of smoked trout has proven to be the use of essential oils. Essential oils are aromatic oily liquids obtained from flowers, buds, seeds, leaves, stem, bark and herbs [10-13]. Essential oils can be used in food in order to prolong the shelf life due to of the natural antioxidant and antimicrobial properties, and additionally, they can reduce or replace synthetics additives plant material. Essential oils and their components have been used for centuries as perfume fragrances, in culinary as flavouring, and in folk medicine [14-17]. Currently, they are mainly studied for their different biological properties such as antioxidant, antibacterial, antiviral, antitumor, antimycotic, analgesic, antiparasitic, antidiabetic, and anti-inflammatory [18-23].

Several studies have shown that some of the essential oils have marked antimicrobial and antioxidant activities in smoked trout such as oregano, thyme, rosemary, clove, cinnamon, coriander, basil, sage and 
$\operatorname{mint}[16,24,25]$. The beneficial effect of the use of natural essential oils on the shelf life of trout products has been confirmed by several researches, for example by using thyme oil the shelf life was increased by $2-5$ weeks $[4,7,24,26-28]$, clove oil by $7-8$ weeks [4, $26,28]$, bay leaves oil by 7 weeks $[6,9]$, sage oil by 6 weeks [4], rosemary oil by 2 - 5 weeks [4, 6], garlic oil by 2 weeks $[24,26]$, oregano oil by $11-12$ days $[7,13,26,27,29]$, basil oil by $10-14$ days [7, 13, 26, 27, 29].

There are studies showing the synergism of action of the mixture of different essential oils or between an essential oil and the content of $\mathrm{NaCl}$ or other antimicrobial agents that can be used to store trout products $[26,30]$.

Rosemary essential oil is a colourless or pale yellow liquid with a characteristic odour of the plant and the many bioactive compounds. Analysis of chemical composition of rosemary oil shows that the most important antioxidant active constituents are phenolic diterpenes, triterpenes, and phenolic acids such as carnosic acid, carnosol, rosmanol, ursolic acid, betulinic acid, and rosmarinic acid. The main constituents of the oils were p-cymene (44.02\%), linalool (20.5\%), gamma-terpinene $(16.62 \%)$, thymol $(1.81 \%)$, betapinene $(3.61 \%)$, alpha-pinene $(2.83 \%)$ and eucalyptol (2.64\%) [31]. It is known that rosemary is a rich source of phenolic phytochemicals having significant antioxidant, anti-inflammatory, hypoglycaemic, hypolipidemic, hypotensive, anti-atherosclerotic, antithrombotic, hepatoprotective, antidepressant, antiproliferative and hypocholesterolaemic effects [32]. Due to its antioxidant and antimicrobial activity, this oil is able to prolong the shelf life of the food and maintain its quality during storage. Therefore, it is already used as an antioxidant and antimicrobial agent in the food industry [33].

Clove oil, an herbal extract, contains the following bio-active natural compounds: eugenol (75.39\%), caryophyllene oxide $(11.22 \%)$ and eugenol acetate (5.16\%). For example, eugenol had antimicrobial properties and inhibited Listeria monocytogenes, Campylobacter jejuni, Salmonella enteritidis, E. coli and Staphylococcus aureus. Clove oil has been listed as a "Generally Regarded as Safe" substance by the United States Food and Drug Administration when administered at levels not exceeding 1,500 ppm in all food categories [27]. Besides the reported antimicrobial, antifungal and antiviral properties, the essential oil of clove shows antiinflammatory, cytotoxic and anaesthetic activities [4, 34, 35].

Oregano essential oil contains carvacrol (64.2\%), pcymene $(17.4 \%), \gamma$-terpinene $(11.3 \%)$, thymol (3.0\%), and linalool $(2.9 \%)$, which are responsible for its biological effect [36]. Also, flavonoids (quercetin, apigenin, kaempferol derivatives) and phenolic acids (rosmarinic, ferulic, p-coumaric, caffeic) confer a potent antioxidant capacity to oregano [37]. Oregano is an important culinary and medicinal plant. Most of the commercial oregano comes from wild plant populations growing in Turkey and Greece.

Traditionally, oregano was employed to treat disorders of the upper respiratory tract, coughs, fever, digestive disorders, dysmenorrhea, rheumatic pains, and urinary disorders [27, 29]. More recently, antihyperglycemic and cytotoxic activities were reported. In the food industry, oregano oil is not only used as a flavouring agent, but also as a preservative, due to significant antimicrobial effects and good antioxidant, antifungal and antibacterial activity $[35,36,38]$.

The paper proposes the use of these three essential oils (rosemary, clove and oregano) in order to increase the shelf life of the vacuum-packaged smoked rainbow trout in vacuum, with the optimal variant taking into consideration the sensory, microbiological and physicochemical analysis of the samples for 91 days chilled storage.

\section{Materials and Methods}

The sample of smoked trout was obtained from a local processor in Suceava, Romania. The trout after smoking is vacuum packaged and has an initial shelf life of 35 days. The three essential oils (rosemary, clove and oregano) were purchased from SC Bionovativ SRL (Braşov, Romania) with known chemical composition. Undiluted $100 \%$ oil of rosemary, clove and oregano oil were used. These essential oils were applied by spraying on the entire surface of the smoked trout prior to packaging, at a rate of $1 \%$ of the weight of the product. The samples were stored during the study under refrigeration conditions at $4-6^{\circ} \mathrm{C}$ and evaluated at $0,14,28,42,56,70,77,84$ and 91 days of storage, respectively, sensory, physicochemical and microbiological characteristics.

Sensory analysis of trout samples treated with essential oils was performed by 35 trained assessors. The sensory panellists comprised students and teachers of the Faculty of Food Engineering, Ștefan cel Mare University of Suceava, Romania, who were selected and trained according to STAS $12655-88$ and STAS $12656-88$ $[44,45]$. Four samples were offered to each panellist: 1 , control sample, smoked trout without essential oil; 2 , smoked trout treated $1 \%$ rosemary oil; 3 , smoked trout treated $1 \%$ clove oil; 4 , smoked trout treated $1 \%$ oregano oil. The panellists were instructed how to evaluate the samples and fill in the form before beginning the evaluation. The following characteristics have been noted: the appearance ( 5 points), the colour and the consistency of the meat ( 5 points), the taste ( 5 points) and the smell ( 5 points), the maximum score that can be obtained by a sample -20 points. The basic principle in the sensory analysis consists in the evaluation of each sensorial characteristic by comparison with scores ranging from 0 to 5 points and the 
FARMACIA, 2019, Vol. 67, 5

achievement of the average score given by the group of panellists $[35,36]$.

Physicochemical analysis. Total volatile basic nitrogen (TVB-N, mg/100 g fish flesh) was determined according to EC Regulation No 2074/2005 [37]. The volatile nitrogenous bases were extracted from a sample using a solution of $0.6 \mathrm{~mol}$ perchloric acid, homogenised for two minutes, and then filtered. After alkalinisation the extract underwent distillation and TVB-N concentration was determined by titration with $0.01 \mathrm{~mol} / \mathrm{L} \mathrm{HCl}$ until $\mathrm{pH}=5$ and calculated using the following equation:

$$
A B V T=\frac{\left(V_{1}-V_{0}\right) \times 0.14 \times 2 \times 100}{M}[\mathrm{mg} / 100 \mathrm{~g}],
$$

where, $\mathrm{V}_{1}=$ volume of $0.01 \mathrm{~mol}$ hydrochloric acid solution in $\mathrm{mL}$ for sample; $\mathrm{V}_{0}=$ volume of $0.01 \mathrm{~mol}$ hydrochloric acid solution in $\mathrm{mL}$ for blank; and $\mathrm{M}=$ weight of sample in $\mathrm{g}$.

The $\mathrm{pH}$ of trout samples was measured by standard method with a portable F2 Standard Mettler Toledo pH-meter (METTLER TOLEDO, Germany).

Determination of ammonia was performed according to SR 9065-7: 2007, relying on the fact that the ammonia ion $\left(\mathrm{NH}_{4}^{+}\right)$gives a yellowish brown colour with Nessler reagent, directly proportional with the amount of ammonia. Interpretation of the results consisted of tracking changes in coloration and clarification of the solution containing the sample to be analysed $[40,41]$.

Kreis reaction is the identification of aldehyde, which is a constant result of advanced fat oxidation according to SR 9065-10:2007. Epihidrinic aldehyde, formed during advanced oxidation of fats, released in an acid environment, reacts with phluoroglucine, giving a coloured compound, proportional to the quantity of

epihidrinic aldehyde, and also with the oxidation process [42-44]. Microbiological analyses

For evaluating the influence of essential oils on the microbiological stability of fish products, several microbiological indicators were assessed: total aerobic counts (Plate Count Agar medium), lactic acid bacteria - LAB (using deMan, Rogosa and Sharpe - MRS Agar), Pseudomonas (CFC Agar medium), Salmonella (Xylose Lysine Deoxycholate - XLD Agar medium) and Enterobacteriaceae (MacConkey Agar), using Merck media (Merck KGaA, Darmstadt, Germany). For sample preparation, $10 \mathrm{~g}$ of product was aseptically collected and homogenized in $90 \mathrm{~mL}$ of sterile physiological saline buffer using a homogenizer BagMixer (InterScience, France). From the homogenized suspension, $1 \mathrm{~mL}$ aliquots were used for inoculation of media, followed by incubation according to the type of media used. For lactic acid bacteria, anaerobic conditions were achieved using an Anaerocult system (Merck KGaA, Darmstadt, Germany). Results were expressed as CFU/g of product after colonies counting. Statistical analysis. All analytical determinations were on days $0,14,28,42,56,70,77,84$ and 91. Experiments were replicated twice on different occasions with different fish samples. The mean each sample for each group was analysed three times. Data were subjected to analysis of variance. The significant difference procedure was used to test for differences between means $(p<0.05)$.

\section{Results and Discussion}

Sensory analysis

The results of the sensory analysis are presented in Table I.

Table I

Synthesis of the scores given in the sensory analysis

\begin{tabular}{|l|c|c|c|c|c|c|c|c|c|}
\hline \multirow{2}{*}{ Sample } & \multicolumn{9}{|c|}{ Storage, days } \\
\cline { 2 - 11 } & $\mathbf{0}$ & $\mathbf{1 4}$ & $\mathbf{2 8}$ & $\mathbf{4 2}$ & $\mathbf{5 6}$ & $\mathbf{7 0}$ & $\mathbf{7 7}$ & $\mathbf{8 4}$ & $\mathbf{9 1}$ \\
\hline Control & 19.5 & 19.4 & 19.0 & 18.8 & 19.2 & 18.0 & 17.9 & 16.5 & 16.8 \\
\hline Rosemary oil & 17.4 & 17.8 & 17.6 & 17.9 & 18.0 & 16.6 & 16.8 & 17.0 & 15.0 \\
\hline Clove oil & 19.6 & 19.5 & 19.4 & 19.2 & 19.2 & 18.8 & 18.6 & 18.8 & 18.0 \\
\hline Oregano oil & 18.6 & 18.4 & 18.2 & 18.5 & 18.0 & 18.2 & 18.0 & 17.5 & 17.0 \\
\hline
\end{tabular}

The analysis of the values presented in Table I shows that smoked trout treated with of clove oil, followed by smoked trout treated with of oregano oil, was among the preferences. These results are agreed by other researches $[5,6,10]$. The samples treated with rosemary oil have been described by the panellists as having a strong smell of rosemary, unpleasant. Under current regulations, unprocessed fishery products belonging to species categories are considered unfit for human consumption if sensorial evaluation gives rise to suspected freshness.

Assessment of physicochemical characteristics

The results of the physicochemical analysis of the smoked trout samples obtained during the 91 days of storage are shown in the Tables II, III, IV and V. 
The results of Total volatile basic nitrogen (TVB-N) evaluation [mg/100 g sample]

\begin{tabular}{|c|c|c|c|c|c|c|c|c|c|}
\hline \multirow{2}{*}{ Sample } & \multicolumn{9}{|c|}{ Storage, days } \\
\hline & $\mathbf{0}$ & 14 & 28 & 42 & 56 & 70 & 77 & 84 & 91 \\
\hline Control & $23.08^{\mathrm{a}} \pm 0.2$ & $23.24^{\mathrm{a}} \pm 0.1$ & $26.04^{\mathrm{b}} \pm 0.3$ & $34.58^{\mathrm{c}} \pm 0.2$ & $45.08^{\mathrm{c}} \pm 0.1$ & $44.75^{\mathrm{d}} \pm 0.2$ & $47.32^{\mathrm{d}} \pm 0.1$ & $48.44^{\mathrm{d}} \pm 0.1$ & $50.60^{\mathrm{d}} \pm 0.1$ \\
\hline Rosemary oil & $23.56^{\mathrm{a}} \pm 0.2$ & $23.94^{\mathrm{a}} \pm 0.1$ & $31.36^{\mathrm{d}} \pm 0.1$ & $34.14^{\mathrm{c}} \pm 0.2$ & $35.14^{\mathrm{b}} \pm 0.2$ & $38.08^{\mathrm{c}} \pm 0.1$ & $39.66^{\mathrm{c}} \pm 0.1$ & $42.56^{\mathrm{b}} \pm 0.3$ & $47.18^{\mathrm{c}} \pm 0.1$ \\
\hline Clove oil & $24.02^{b} \pm 0.3$ & $24.78^{b} \pm 0.2$ & $24.08^{\mathrm{a}} \pm 0.1$ & $28.77^{\mathrm{b}} \pm 0.1$ & $29.02^{\mathrm{a}} \pm 0.1$ & $29.44^{\mathrm{a}} \pm 0.3$ & $30.80^{\mathrm{a}} \pm 0.2$ & $38.08^{\mathrm{a}} \pm 0.3$ & $40.88^{\mathrm{a}} \pm 0.2$ \\
\hline Oregano oil & $23.98^{\mathrm{a}} \pm 0.1$ & $24.05^{\mathrm{a}} \pm 0.1$ & $28.28^{\mathrm{c}} \pm 0.2$ & $27.37^{\mathrm{a}} \pm 0.1$ & $35.28^{\mathrm{b}} \pm 0.1$ & $35.28^{\mathrm{b}} \pm 0.1$ & $32.48^{\mathrm{b}} \pm 0.2$ & $43.96^{\mathrm{c}} \pm 0.1$ & $44.85^{\mathrm{b}} \pm 0.1$ \\
\hline
\end{tabular}

Generally, the total volatile basic nitrogen (TVB-N) may be considered as a quality index for fish. Its increase is related to the activity of spoilage bacteria and endogenous enzymes [5]. At the beginning of storage, the TVB-N value was $23.08 \mathrm{mg} / 100 \mathrm{~g}$ (Table II) smoked trout for control sample and 23.56 $24.02 \mathrm{mg} / 100 \mathrm{~g}$ for smoked trout treated with essential oil. These values were approximately similar to the values reported by [10] for hot smoked rainbow $(23.22 \mathrm{mg} / 100 \mathrm{~g})$ [10]. According to the EC Regulation No 2074/2005, unprocessed fishery products belonging to species categories are considered unfit for human consumption if TVB-N value exceeds $35 \mathrm{mg} / 100 \mathrm{~g}$ trout [43]. The best results were obtained in the case of clover oil, an increase in this indicator was observed after a 91 days of storage period of 1.8 times the control sample, the increase of which was 2.17 times. These results agree with those obtained by Lee et al. which found that in addition, the shelf life of smoked fish treated with clove oil was extended by $4-5$ weeks compared to the control samples [22]. Erkan $\mathrm{N}$. has come to the conclusion that a shelf life of 7 weeks was recorded for hot smoked trout treated with thyme and garlic oil [24]. Research conducted by Çoban et al. showed that combination of vacuum and essential oils extension shelf life of approximately 2-8 weeks [4].

Table III

Evolution of smoked trout $\mathrm{pH}$ during storage

\begin{tabular}{|l|c|c|c|c|c|c|c|c|c|}
\hline \multirow{2}{*}{ Sample } & \multicolumn{8}{c|}{ Storage, days } \\
\cline { 2 - 9 } & $\mathbf{0}$ & $\mathbf{1 4}$ & $\mathbf{2 8}$ & $\mathbf{4 2}$ & $\mathbf{5 6}$ & $\mathbf{7 0}$ & $\mathbf{7 7}$ & $\mathbf{8 4}$ & $\mathbf{9 1}$ \\
\hline Control & $5.80^{\mathrm{a}} \pm 0.01$ & $6.13^{\mathrm{a}} \pm 0.03$ & $6.16^{\mathrm{a}} \pm 0.01$ & $6.10^{\mathrm{a}} \pm 0.01$ & $6.05^{\mathrm{a}} \pm 0.02$ & $5.95^{\mathrm{a}} \pm 0.03$ & $5.99^{\mathrm{a}} \pm 0.01$ & $6.00^{\mathrm{a}} \pm 0.02$ & $5.97^{\mathrm{a}} \pm 0.01$ \\
\hline Rosemary oil & $5.75^{\mathrm{a}} \pm 0.02$ & $5.95^{\mathrm{a}} \pm 0.01$ & $6.02^{\mathrm{a}} \pm 0.02$ & $6.01^{\mathrm{a}} \pm 0.02$ & $5.99^{\mathrm{a}} \pm 0.02$ & $6.00^{\mathrm{a}} \pm 0.01$ & $5.94^{\mathrm{a}} \pm 0.03$ & $5.98^{\mathrm{a}} \pm 0.01$ & $5.94^{\mathrm{a}} \pm 0.02$ \\
\hline Clove oil & $5.87^{\mathrm{a}} \pm 0.01$ & $6.28^{\mathrm{b}} \pm 0.01$ & $6.37^{\mathrm{b}} \pm 0.01$ & $6.32^{\mathrm{b}} \pm 0.02$ & $6.25^{\mathrm{b}} \pm 0.01$ & $6.24^{\mathrm{b}} \pm 0.01$ & $6.20^{\mathrm{b}} \pm 0.02$ & $6.19^{\mathrm{b}} \pm 0.02$ & $6.22^{\mathrm{b}} \pm 0.01$ \\
\hline Oregano oil & $5.78^{\mathrm{a}} \pm 0.02$ & $6.16^{\mathrm{a}} \pm 0.02$ & $6.27^{\mathrm{b}} \pm 0.03$ & $6.32^{\mathrm{b}} \pm 0.01$ & $6.15^{\mathrm{b}} \pm 0.01$ & $6.22^{\mathrm{b}} \pm 0.02$ & $6.05^{\mathrm{a}} \pm 0.01$ & $6.12^{\mathrm{b}} \pm 0.01$ & $6.05^{\mathrm{a}} \pm 0.03$ \\
\hline
\end{tabular}

(Different letters in the same column represent statistically significant differences for $\mathrm{p}<0.05$ )

At the beginning of the evaluation period, the $\mathrm{pH}$ value was 5.80 for control sample and 5.78, 5.75 and 5.87 for smoked trout treated with essential oil. At the end of the storage period of 91 days, $\mathrm{pH}$ values of samples were found to be 5.97 for control sample, respectively 5.94 for smoked trout treated with rosemary oil, 6.22 for smoked trout treated with clove oil and 6.05 for smoked trout treated with oregano oil. Similar results have been reported for hot smoked rainbow trout under vacuum conditions [24].

Table IV

The results of the determination of the fat oxidation stage (Kreis reaction)

\begin{tabular}{|l|c|c|c|c|c|c|c|c|c|}
\hline \multirow{2}{*}{\multicolumn{1}{|c|}{ Sample }} & \multicolumn{7}{|c|}{ Storage, days } \\
\cline { 2 - 11 } & $\mathbf{0}$ & $\mathbf{1 4}$ & $\mathbf{2 8}$ & $\mathbf{4 2}$ & $\mathbf{5 6}$ & $\mathbf{7 0}$ & $\mathbf{7 7}$ & $\mathbf{8 4}$ & $\mathbf{9 1}$ \\
\hline Control sample & - & - & - & - & + & + & + & + & + \\
\hline Rosemary oil & - & - & - & - & - & - & + & + & + \\
\hline Clove oil & - & - & - & - & - & - & - & - & - \\
\hline Oregano oil & - & - & - & - & + & + & + & + & + \\
\hline
\end{tabular}

The qualitative test performed by the Kreis reaction led to the best results for the smoked trout treated with clove oil, where the reaction was "negative" from the first day until the last day of storage (Table IV). An identical result was obtained in the case of ammonia determination with the Nessler reagent (Table V).

Table V

Results of determination of ammonia with Nessler reagent

\begin{tabular}{|c|c|c|c|c|c|c|c|c|c|}
\hline Sample & \multicolumn{10}{|c|}{ Storage, days } \\
\hline & $\mathbf{0}$ & $\mathbf{1 4}$ & $\mathbf{2 8}$ & $\mathbf{4 2}$ & $\mathbf{5 6}$ & $\mathbf{7 0}$ & $\mathbf{7 7}$ & $\mathbf{8 4}$ & $\mathbf{9 1}$ \\
\hline Control sample & - & - & - & - & + & + & + & + & + \\
\hline Rosemary oil & - & - & - & - & - & - & + & + & + \\
\hline Clove oil & - & - & - & - & - & - & - & - & - \\
\hline Oregano oil & - & - & - & - & + & + & + & + & + \\
\hline
\end{tabular}


One of the problems derived from food degradation is lipid oxidation and peroxidation. These two processes are natural chemical phenomena that affect the nutritional value of foods, and they are responsible for changes in foods sensorial characteristics. The antioxidant capacity of the essential oils is directly related to their composition. Their strong antioxidant capacity may be also explained by the synergistic effect among active compounds. [32].

Assessment of microbiological characteristics

Fish microbial spoilage is known to occur from specific classes of microorganisms, depending on the origin of the product and on the technological processes used. In fresh fish, Gram-fermentative bacteria such as Vibrionaceae are main spoilage agents, in marine and chilled fish Shewanella and Pseudomonas are predominant, while in cold smoked fish, chilled, vacuum-packed fish lactic bacteria dominates (LAB), sometimes associated with psychrotrophic Enterobacteriaceae [15]. In smoked, chilled, vacuum packed fish, microbial counts should be complementary, as only total bacterial counts may prove irrelevant due to high numbers of LAB that are present for weeks before product becomes sensorially inacceptable. In these products, microflora may be composed by LAB alone, LAB and Enterobacteriaceae or Photobacterium phosporeum and LAB [16].

The dynamics of microbial populations of fish samples presented, as expected, a growing trend over the 91 days of storage (Figures 1 and 2). Both aerobic plate counts and lactic bacteria counts had highest values in control samples, reaching differences of $1 \log$ compared to treated samples. The effectiveness of the essential oils decreased in the next way: clove oil, oregano oil and rosemary oil.

Generally, the highest increase in bacterial counts between analyses was observed after 56 days in the case of control fish and after 91 days in the case of the essential oils. Enterobacteriaceae were also detected in fish samples, but only up to 28 days, reaching, at 14 days, $3.81 * 10^{3}, 2.20 * 10^{3}, 2.80 * 10^{3}$ and $2.50 * 10^{3}$ $\mathrm{CFU} / \mathrm{g}$ in control, clove, rosemary and oregano samples, respectively. After 28 days, control samples had $1.65 * 10^{2} \mathrm{CFU} / \mathrm{g}$ Enterobacteriaceae while other samples recorded no such microorganisms. After 56 days, Enterobacteriaceae were not detected in any treatments. Pseudomonas and Salmonella were not detected.

Our results are in agreement with other research, where main microorganisms in smoked trout were LAB, followed by Enterobacteriaceae [13]. The smaller numbers in our study may be the result of fish origin and smoking process characteristics. Clove and rosemary oils have been reported previously as effective storage period extenders of smoked and vacuumed trout, due to inhibitory effects of essential oils on lipid oxidation and microbiological growth [7]. From a microbiological standpoint, the effect of clove and oregano essential oils is due to the main compounds thymol and eugenol, which alter microbial cell envelope [31]. More specifically, eugenol modifies membrane permeability and fatty acid profile and is also active against bacterial enzymes such as proteases, amylases and ATPase [23]. Comparing clove and oregano oils with rosemary oil, the former had higher efficacy, which can be a result of different chemical composition. Rosemary oil has 1,8 -cineole and $\alpha$-pinene as major compounds and is slightly less effective than clove oil against G-, $\mathrm{G}+$ bacteria and fungi [11].

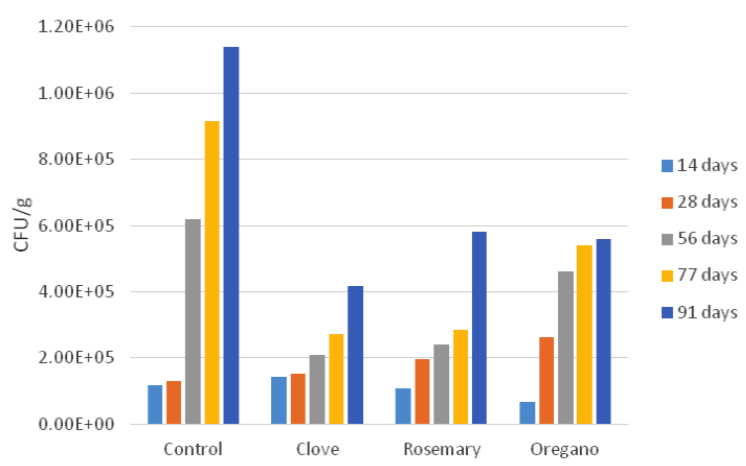

Figure 1.

Total aerobic counts dynamics of smoked trout

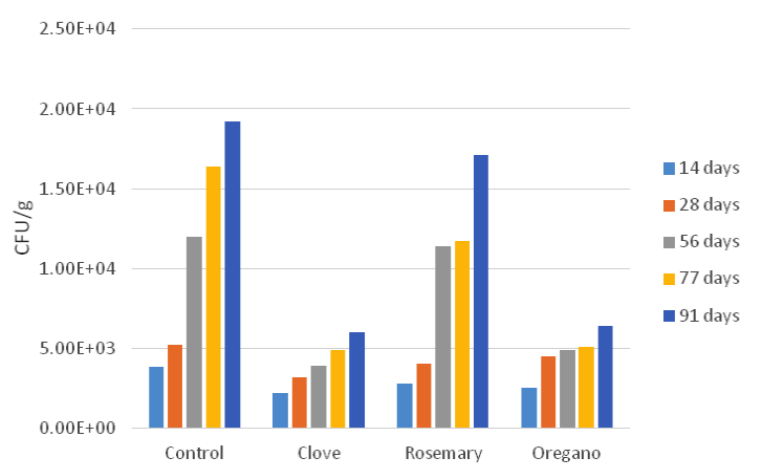

Figure 2.

Lactic bacteria counts dynamics of smoked trout

\section{Conclusions}

The addition of essential oil on smoked trout has a real benefit for the finished products. The results of the present studies lead to an increase of the shelf life of vacuum-packaged hot smoked trout to over $100 \%$. The initial shelf life of the control sample was 35 days, but with the addition of essential oil it can be increased up to 90 days (2.6 times higher). According to sensorial physicochemical and microbiological analyses, the essential oils have a positive effect on the shelf life of finished product; especially addition of clove oil extended the products shelf life by approximately 8 weeks. In conclusion, essential oils can be used to improve smoked trout shelf life as natural preservatives. 


\section{Acknowledgement}

This work was supported by a grant of the Romanian Ministry of Research and Innovation, CCCDI UEFISCDI, project number PN-III-P2-2.1-CI-20170097, within PNCDI III.

\section{References}

1. Behnam S, Anvari M, Rezaei M, Soltanian S, Safari $\mathrm{R}$, Effect of nisin as a biopreservative agent on quality and shelf life of vacuum packaged rainbow trout stored at $4^{\circ} \mathrm{C}$. J Food Sci Tech., 2015; 52(4): 2184-2192.

2. Rhayour K, Bouchikhi T, Tantaoui-Elaraki A, Sendide K, Remmal A, The Mechanism of Bactericidal Action of Oregano and Clove Essential Oils and of Their Phenolic Major Components on Escherichia coli and Bacillus subtilis. J Ess Oil Res., 2011; 15(5): 356-362.

3. Cakli S, Kilinc B, Dincer T, Tolasa S, Comparison of the shelf lifes of map and vacuum packaged hot smoked rainbow trout. Eu Food Res Tech., 2006; 224: $19-26$

4. Çoban Ö, Bahri P, Yilmaz Ö, Protective effect of essential oils on the shelf life of smoked and vacuum packed rainbow trout fillets. J Food Sci Tech., 2014; 51(10): 2741-2747.

5. Yildiz PO, Combine Effects of Essential Oils and Packaging on Smoked Rainbow Trout Stored $4^{\circ} \mathrm{C}$. Pack Tech Sci., 2015; 28: 987-997.

6. Erkan N, Ulusoy S,, Tosun Y, Effect of combined application of plant extract and vacuum packaged treatment on the quality of hot smoked rainbow trout. J Consum Protect Food Saf., 2011; 6: 419-426.

7. Gómez-Estaca J, López de Lacey A, López-Caballero ME, Gómez-Guillén MC, Montero P, Biodegradable gelatin-chitosan films incorporated with essential oils as antimicrobial agents for fish preservation. Food Microb., 2010; 27(7): 889-896.

8. Gonzalez-Rodrigues MN, Sanz JJ, Santos JA, Otero A, Garcia-Lopez ML, Numbers and types of microorganisms in vacuum-packed cold-smoked freshwater fish at the retail level. Int J Food Microb., 2002; 77: $161-168$

9. Irkin R, Esmer OK, Novel food packaging systems with natural antimicrobial agents. J Food Sci Tech., 2015; 52(10): 6095-6111.

10. Lee S, Najiah M, Wendy W, Nadirah M, Chemical composition and antimicrobial activity of the essential oil of Syzygium aromaticum flower bud (Clove) against fish systemic bacteria isolated from aquaculture sites. Front Agric China, 2009; 3(3): 332-336.

11. Reyes-Jurado F, Franco-Vega A, Ramírez-Corona N, Palou E, López-Malo A, Essential Oils: Antimicrobial Activities, Extraction Methods, and Their Modeling. Food Engin Rev., 2015; 7: 275-297.

12. Shokri S, Ali Ehsani A, Jasour MS, Efficacy of Lactoperoxidase System-Whey Protein Coating on Shelf-life Extension of Rainbow Trout Fillets. Food Bioproc Tech., 2015; 8: 54-62.

13. Singh S, Lee M, Park I, Shin Y, Antimicrobial seafood packaging: a review. J Food Sci Tech., 2016; 53(6): 2505-2518
14. Gram L, Huss SS, Microbiological spoilage of fish and fish products. Int J Food Microb., 1996; 33: 121-137.

15. Gram L, Dalgaard P, Fish spoilage bacteria - problems and solutions. Cur Opin Biotech., 2002, 13(3): 262-266.

16. Dobre AA, Gagiu V, Nivulita P, Antimicrobial activity of essential oils against food-borne bacteria evaluated by two preliminary methods. Ro Biotech Lett., 2011, 16(6)-supplement: 119-125.

17. Zgârian RB, Iacob F, Alpaslan Kaya D, Rău I, Voicu G, Tihan GT, Effect of different essential oils on human dentine structure. Farmacia, 2017; 65(2): 247-251.

18. Fu Y, Zu Y, Chen L, Shi X, Wang Z, Sun S, Efferth T, Antimicrobial activity of clove and rosemary essential oils alone and in combination. Phytother Res., 2007; 21: 989-994

19. Hernández-Ochoa L, Aguirre-Prieto YB, NevárezMoorillón GV, Gutierrez-Mendez N, Salas-Muñoz E, Use of essential oils and extracts from spices in meat protection. J Food Sci Tech., 2014; 51(5): 957-963.

20. Marchese A, Barbieri R, Coppo E, Orhan IE, Daglia M, Nabavi SF, Izadi M, Abdollahi M, Nabavi SM, Ajami M, Antimicrobial activity of eugenol and essential oils containing eugenol: A mechanistic viewpoint. Crit Rev Microb., 2017; 43(6): 668-689.

21. Mititelu M, Ioniţă C, Moroşan E, Research regarding integral processing of mussels from Black Sea. Farmacia, 2014; 62(3): 625-632.

22. Ribeiro-Santos R, Andrade M, Sanches-Silva A, Ramos de Melo N, Essential Oils for Food Application: Natural Substances with Established Biological Activities. Food Bioproc Tech., 2018; 11: 43-71.

23. Sacchetti G, Maietti S, Muzzoli M, Scaglianti M, Manfredini S, Radice M, Bruni R, Comparative evaluation of 11 essential oils of different origin as functional ingredients for food as antioxidants, antiradicals and antimicrobials. Food Chem., 2005; 91: 621-632.

24. Erkan N, The Effect of Thyme and Garlic Oil on the Preservation of Vacuum-Packaged Hot Smoked Rainbow Trout. Food Bioproc Tech., 2012; 5: 12461254.

25. Xing Y, Li X, Xu Q, Yun J, Lu Y, Antifungal activities of cinnamon oil against Rhizopus nigricans, Aspergillus flavus and Penicillium expansum in vitro and in vivo fruit test. J Food Sci Tech., 2010; 45(9): $1837-1842$.

26. Sanchez-Gonzales L, Vargas M, González-Martínez C, Chiralt A, Cháfer M, Use of Essential Oils in Bioactive Edible Coatings. Food Engin Rev., 2011; 3: 1-16.

27. Jouki M, Yazdi FT, Mortazavi SA, Koocheki A, Khazaei N, Effect of quince seed mucilage edible films incorporated with oregano or thyme essential oil on shelf life extension of refrigerated rainbow trout fillets. Int J Food Microb., 2014; 17: 88-97.

28. Yildiz PO, Combine Effects of Essential Oils and Packaging on Smoked Rainbow Trout Stored $4^{\circ} \mathrm{C}$. Pack Tech Sci., 2015; 28: 987-997.

29. Mexis SF, Chouliara E, Kontominas MG, Combined effect of an oxygen absorber and oregano essential oil on shelf life extension of rainbow trout fillets stored at $4^{\circ}$ C. Food Microb., 2009; 26(6): 598-605. 
30. Viuda-Martos M, Navajas YR, Sánchez Zapata E, Fernández López J, Pérez Álvarez J, Antioxidant activity of essential oils of five spice plants widely used in a Mediterranean diet. Flav Fragr J., 2010; 25(1): 13-19.

31. Hassani FV, Shirani K, Hosseinzadeh H, Rosemary (Rosmarinus officinalis) as a potential therapeutic plant in metabolic syndrome: a review. NaunynSchmiedeberg's Arch Pharmac., 2016; 389: 931-949.

32. Özcan MM, Chalchat JC, Chemical composition and antifungal activity of rosemary (Rosmarinus officinalis L.) oil from Turkey. Int J Food Sci Nutr., 2008; 59(7-8): 691-698.

33. Rašković A, Milanović I, Pavlović N., Ćebović T, Vukmirović S, Mikov M, Antioxidant activity of rosemary (Rosmarinus officinalis L.) essential oil and its hepatoprotective potential. BMC Compl Alt Med., 2014; 14: 225.

34. Javahery S, Nekoubin H, Moradlu AH, Effect of anaesthesia with clove oil in fish (review). Fish Phys Biochem., 2012; 38: 1545-1552.

35. Velescu BŞ, Anuţa V, Niţulescu GM, Olaru OT, Orțan A, Ionescu D, Ghica MV, Drăgoi CM, Dinu Pîrvu CE, Pharmaceutical assesment of Romanian crops of Anthriscus sylvestris (Apiaceae). Farmacia, 2017; 65(6): 824-831.

36. Grondona E, Gatti G, López A, Sánchez LR, Rivero V, Pessah O, Zunino M, Ponce A, Bio-efficacy of the Essential Oil of Oregano (Origanum vulgare
Lamiaceae. ssp. Hirtum). Plant Foods Human Nutr., 2014; 69: 351-357.

37. Antal D, Citu C, Ardelean F, Dehelean C, Vlaia L, Soica C, Vlaia V, Biris M, Sas I, Metallome of Origanum vulgare: the unknown side of a medicinal and aromatic plant used worldwide. Farmacia, 2015; 63(4): 534-538.

38. Pezzani R, Vitalini S, Iriti M, Bioactivities of Origanum vulgare L.: An update. Phytochem Rev., 2017; 16: 1253-1268.

39. Terenina MB, Misharina TA, Krikunova NI, Alinkina ES, Fatkulina LD, Vorobyova AK, Oregano essential oil as an Inhibitor of higher fatty acid oxidation. App Biochem Microb., 2011, 47(4): 445-449.

40. *** Commission Regulation (EU) 2074/2005, Total Volatile Basic Nitrogen (TVB-N) limit values for certain categories of fishery products and analysis method to be used.

41. *** SR 9065-7: 2007, Determination of ammonia with Nessler reagent.

42. *** SR 9065-10:2007, Methods for estimating the stage of fat oxidation (Kreiss reaction and peroxide index).

43. *** STAS 12655-88, Food. Sensory analysis. Conditions for tasters.

44. *** STAS 12656-88, Food. Sensory analysis. Methods with scoring scale. 